\title{
A Study of Employee Welfare Leading to Corporate Sustainability in Garments Industries of Bangladesh
}

\author{
Mansura Nusrat $^{1 *}$, Mohammad Solaiman ${ }^{2}$ \\ ${ }^{1}$ Lecturer, Department of Business Administration, Bangladesh University, Dhaka, BANGLADESH \\ ${ }^{2}$ Deputy Director, Governance Innovation Unit, Prime Ministers' Office, Dhaka, BANGLADESH \\ *E-mail for correspondence: brupeen@gmail.com
}

\begin{abstract}
Employee welfare is an area of social welfare, which covers a broad field of Corporate Sustainability and connotes a state of well-being, happiness, satisfaction, conservation and development of human resources. Evidences from contemporary literature suggest that employee welfare contributes to the sustainability of the business significantly. This paper is based on descriptive and inferential research. This study has tried to measure the extent to which the garments industries in Chittagong city of Bangladesh are providing their employees (plant level) with welfare facilities. The findings of this study suggests that most of the sample farms offer welfare benefits to their employees and such benefits have improved the productivity and sustainability of the business. The study also opens avenue for further research in this field considering employee welfare reporting as a tool for corporate sustainability in the developing counties.
\end{abstract}

Keywords: Readymade Garments, Employee welfare Facilities, Sustainability, Productivity, Satisfaction, Bangladesh

\section{INTRODUCTION}

Employee welfare is broader term that includes various services, benefits and facilities offered to employees by the employers, which have both immediate and long term impact on the performance and efficiency of the employees as well as their personal and social lives. They include issues such as allowances, housing, transportation, medical care, child care, recreational facility, hygienic sanitary facility, on time bonus and overtime payments, insurance and food. Employee welfare also includes monitoring of working conditions, creation of industrial harmony through infrastructure for health, industrial relations and insurance against disease, accident and unemployment for the workers and their families. Through such generous benefits the employer makes life worth living for employees that consequently make the business more sustainable in the long run both from the economic and social point of views (JetHR, 2015).

The Ready Made Garments (RMG) industry of Bangladesh has a significant contribution in the country's consistent $6 \%$ annual GDP growth rate in recent years. It has contributed not only in the export sector of the country, but it has created considerable amount of jobs mostly for women contributing to their economic and social empowerment. The Made in Bangladesh tag in the Bangladeshi garments products have travelled across the world as an emblem of social and economic freedom of Bangladeshi women, which have also contributed to the sustainability of their companies (Hasan, 2014).
Srinivas (2013) observes that organizations provide welfare measures to their employees to promote the efficiency of the employees, to keep their motivation level high, to promote healthy industrial relation, to get loyal services from the employees and to add in the real way to the low earnings of the workers. In spite of all modern technology and developed systems, plant level workers remain the most important factor of production in readymade garments. Evidences suggest that motivation through various employee welfare activities is crucial for consistency in productivity and achieving organisational goal (Kongala, 2013; Borman, 2000; Webb and Blandin, 2006).

In the following parts of this article, the existing employee welfare facilities and their impact to the long term business sustainability of the sample RMG companies of Bangladesh have been examined and analyzed.

\section{LITERATURE REVIEW}

Theoretical Framework of Employee Welfare and Corporate Sustainability

Employee welfare falls within the social sect of the Triple Bottom Line theory of business which, along with its other two sects such as economic and environment leading to the sustainability of the business (Slaper and Hall, 2011). The Stakeholder theory of business also refers that the management of a business should also put emphasis on all the stakeholders' interest such as the employees' welfare instead of only maximizing the 
profits of the shareholders (Phillips, 2003). Venugopal et al. (2011) suggest that employee welfare has derived from the broader concept of social welfare that refers to the well being of the human resources of an organization that incorporates every possible kind of satisfaction and motivation of the employees to serve the organization.

Gedenne et al. (2012), in their study of the sustainability performance of Australian companies, find that employee welfare comprising of the development of employees' personal and social life-standard and working conditions have a significant contribution to the company's performance and sustainability.

Patro (2012) suggests that employee welfare facilities can be broadly categorized into two groups:

- Intramural facilities: These are provided within the establishment Like: Drinking Water, toilet, canteen, medical care.

- Extramural facilities: These are activities which are undertaken outside the establishment Like: Child care, housing, transportation, sports facility.

Every Employee, the author continues, including people with disabilities should get the right facility in the workplace, which is not a very time consuming or complicated task.

\section{Employee Welfare and Sustainability}

Employee welfare, from a broader and holistic point of view, significantly contributes to the psychology of the employees to whom the workplace is not a mere money earning place (Rynes et al., 2004). One of the major objectives of employee welfare is to maintain safe and sound working environment so that the employees develop a sense of ownership for the company which consequently leads to the stable productivity, economic development and sustainability of business (Odeku and Odeku, 2014). Tiwary (2014) suggests that the employee welfare measures have positive correlation to both mental and physical health of the employees which directly contributes to their efficiency, productivity and the sustainability of the business. Similarly, Sindhu (2012) observes that employee welfare facilities motivates the employees and create a sense of ownership of their work which make the farm perform for longer time. The study of Iqbal and Yilmaz (2014) finds positive correlation between work place environment and corporate sustainability. However, Symons and Lamberton (2014) suggest that the sustainability of business is not solely dependent upon employee welfare and there are other issues such as competitive business advantages and financial matters.

\section{Present scenario of Bangladesh Readymade Garments}

Readymade garments industry emerged as one of the post independence industrial enterprises in Bangladesh when the country was suffering from huge unemployment and lack of resource due war time destructions (Hassan 2014).
The RMG industry now, Hassan (2014) continues, is currently the highest export earning source in Bangladesh comprising $81 \%$ of total export.

According to a World Bank report of 2013, the readymade garment (RMG) sector in Bangladesh has created 3.6 million direct jobs, contributed 13 per cent of the gross domestic product (GDP) and fetched over 75 per cent of foreign exchange earnings in 2012 (Ahmed 2014). Bangladesh exported garment products worth US $\$ 24.5$ billion in the fiscal year 2013-14, higher by 13.86 per cent than that of the previous fiscal year despite a prolonged political crisis and two major industrial disasters like the Tazreen Fashions fire and the Rana Plaza building collapse, where more than 1,100 workers died (Bhowmik, 2014). These two disasters affected the industry severely as Hossain (2104) observed that around 220 small and medium factories were shut down and global watchdog organisation such as Accord and Alliance closed 29 more factories after inspection.

According to a 2011 study by McKinsey and Company (Bangladesh's readymade garments landscape: The challenge of growth), Bangladesh's RMG sector, with 5,000 factories employing about 3.6 million of workers out of a workforce of over 75 million (Ahmed 2014). ILO (2015) observes that the remarkable growth of RMG sector in Bangladesh has been challenged by insufficient safety facilities and frequent accidents indicating the significant amount of risk in this sector.

\section{Objectives of the Study}

The objectives of this study are following:

- Understanding the employee welfare facilities provided by the RMG factories in Chittagong City.

- $\quad$ Studying the employee welfare facilities provided in the RMG factories in Chittagong city from a sustainability point of view.

- Suggesting recommendations on employee welfare for sustainable business.

\section{MetHodology}

Both descriptive and inferential research were conducted to identify different dimensions of employee welfare facilities of garments industry, such as Medical care, Child care, rest room facility, Fire safety measure in Bangladesh. The focus of the research is the lower level male and female workers of the garments industries located in Chittagong city. Both primary and secondary sources were used in this study. Primary data was collected through a structured questionnaire (with a likert type 5 point scale). The population of this study included all Ready Made Garments industries in Chittagong city of Bangladesh. A random sample of 130 garment workers was chosen from 10 garments industries of Chittagong city. For primary data, interview survey were carefully designed and conducted to evaluate the performance of the garments industries. 
Secondary data were collected by consulting official documents of garments industries, internet, industry manuals, audit reports, articles, etc. the data were collected during 2014-2015.

Statistical Package of Social Sciences (SPSS Software) was used for analyzing data. Means and Standard deviations were analyzed for each item. A left-tailed Z-test was used to determine whether the garments industries are providing their employees with enough employee welfare facilities.

\section{HyPOTHESES}

$H_{0}$ : Garments industries in Chittagong are providing enough employee welfare facilities.

$H_{1}$ : Garments industries in Chittagong are not providing enough employee welfare facilities.

\section{EMPIRICAL FINDINGS}

This study has tried to measure the extent to which the Garments industries are providing their employees (plant level) with welfare facilities. Collected data were analyzed and interpreted in line with the objectives of this study. From the analysis the mean and standard deviation of all variables have been calculated separately. Means are indicative of the variables acceptability, whereas standard deviations are indicative of deviations among the respondents.

The respondents were asked about bonded labor in the Organization. In responses to this question 41.5 percent of the respondents strongly agree that their organization do not engage in forced labor while 33.07 percent of the respondents agree to about this statement, with a mean of 3.91 which lies in between agree and neutral of the scale and the standard deviation is 1.25. The respondents were asked about Medical care given by the organization. In response to this question 25.38 percent of the respondents strongly agree that their organization provide enough medical care though a significant number of employees (23.84 percent) disagree about this statement. With a mean of 3.20 which lies in between agree and neutral of the scale and the standard deviation is 1.46. It is observed from the analysis that 30.77 percent of employees agree about the fact that their organization give assistance regarding child care, with a mean of 3.34 which lies within agree and neutral and the standard deviation is 1.46. It is noted from the analysis that 49 employees out of 130 believes that rest room facilities provided by the organization is sufficient, with a mean of 3.89, which lies within the agree and neutral and standard deviation is 1.11. Although 34.62 percent of respondent agree with the statement that their organizations support in participating at spiritual activities, the 20.77 percent of the employees disagree with this. The mean is 3.23 and the standard deviation is 1.33 here.
Although a significant number $(36.15 \%)$ of respondents agree that organization has sufficient fire safety measurements, 19.23 percent respondents disagree with that. In this case the mean is 3.54, which lies within agree and neutral and the standard deviation is 1.37. Organization facilitates with safe drinking water- 58 respondents strongly agree with this statement, while 16 respondents disagree with this. Here mean is 3.85 , which lies between agree and neutral and standard deviation is 1.35. When the respondents were asked about whether the organization has adequate lighting and ventilation system or not 36.15 percent strongly agree, when 29.23 percent agree to this query. In this case the mean is 3.65, which lies within agree and neutral and the standard deviation is 1.39. When 20.77 percent of respondents opined neutral regarding the statement organization has hygienic sanitary facility, the other 26.92 percent disagree. Here the mean is 2.82 , which lies within disagree and neutral and the standard deviation is 1.29. From the analysis it is found that 26.15 percent respondents agree to that organization has dining arrangements, although 21.54 percent strongly disagree to this. Here the mean is 3.02, which lies within agree and neutral and the standard deviation is 1.29 .

The respondents were asked whether the organization provide enough festival bonuses. In responses to this question 28.46 percent of the respondents strongly agree to that statement, while 21.54 percent of the respondents agree on this statement, with a mean of 2.88 which lies in between disagree and neutral of the scale and the standard deviation is 1.62. The respondents were asked whether organization provide enough overtime payment. In response to this question 36.92 percent of the respondents strongly agree that their organization provide enough overtime payment, while a significant number of employees (36.45percent) agree about this statement. With a mean of 3.92 which lies in between agree and neutral of the scale and the standard deviation is 1.11. It is observed from the analysis that 20.76 percent of respondents agree about the fact that their organization sufficient transportation facility, while 27.69 percent respondents disagree with this statement, with a mean of 2.85 which lies within disagree and neutral and the standard deviation is 1.34 . It is noted from the analysis that 47 employees out of 130 opined that organization provide attendance bonus, with a mean of 3.69 , which lies within agree and neutral comprising the standard deviation of 1.38. While 26.92 percent of respondent strongly disagree with the statement that their organizations provide efficiency bonus equitably, the 25.38 percent of the respondents disagree with this, with a mean of 2.66 which lies within disagree and neutral and the standard deviation is 1.40 .

It is noted that a significant number (36.15\%) of respondents disagree that organization provide production bonus, 36.15 percent respondents disagree with that. In this case the mean is 2.37, which lies within disagree and 
neutral and the standard deviation is 1.31 . Organization arranges recreational facilities- 46 respondents strongly disagree with this statement, while 44 respondents disagree with this. Here mean is 2.3 , which lies between disagree and neutral and standard deviation is 1.36 . When the respondents were asked about whether the organization provides equal employment opportunity, 34.62 percent of them strongly agreed, while 27.69 percent being agreed. In this case the mean is 3.67 , which lies within agree and neutral and the standard deviation is 1.29.

Analyses of the secondary data suggest that, the employer's association of RMG sector of Bangladesh is committed to maintain a violence free working environment. Individuals who commit any kind of act of violence (Violence, Threats of violence, and other disruptive behavior) might be removed from the premises and could be considered for disciplinary action. However 33.08 percent of respondents opined "strongly agree" regarding the statement organization does not have workplace violence, while the other 21.54 percent disagreed. Here the mean is 3.34 , which lies within agree and neutral and the standard deviation is 1.47. From the analysis it is found that 42.30 percent respondents strongly agree to that employees are not harassed by the top level employees, while 29.23 percent agree to this. Here the mean is 3.89 , which lies within agree and neutral and the standard deviation is 1.24. Any kind of harassments including harassments by co-workers, customers, vendors, agents or any other third parties are strictly monitored and taken action in the RMG factories in Chittagong. The findings retrieved from the responses of the respondents suggests that most of the RMG factories of Chittagong city tend to provide basic employee welfare facilities. However, the point of sustainability of the business appears yet to be achieved as the findings in several cases such as medical facilities, workers' hygienic facilities, recreational facilities, and various performance incentives suggest arising significant amount of disagreements among the respondents.

\section{HYPOTHESES TESTING}

In the case of having a null hypothesis and an alternative hypothesis, the left tailed test (wherein there is one rejection region only on the left tail) is considered appropriate. The test suggests that $95 \%$ acceptance zone (confidence level) confirms 0.45 of left area and 0.5 of right area. From the normal distribution table it can be found that the appropriate $\mathrm{Z}$ value for $5 \%$ significant level is -1.645 .

Mathematically we can state:

Acceptance Region A: Z > -1.645

Rejection Region R: $Z \leq-1.645$

From the empirical study, it is found that the mean of means of the statements $\left(\mu_{\bar{X}}\right)$ is 3.35 and standard deviation of means of the statements $(\sigma)$ is 0.52 .
Therefore, the Standard Error, $\sigma_{\bar{X}}=\frac{\sigma}{\sqrt{n}}=\frac{0.52}{\sqrt{20}}=$ 0.116

Now the Standardized Variable,

$\mathrm{Z}=\frac{\bar{X}-\mu_{\bar{X}}}{\sigma_{\bar{X}}}$ or $\bar{X}=\mathrm{Z} \times \sigma_{\bar{X}}+\mu_{\bar{X}}$

Hence, the Lower Limit of accepted means is $\bar{X}=$ $-1.645 \times 0.116+3.35=3.16$

From the analysis it is revealed that the means of thirteen statements lie within the acceptance zone and seven fall outside the acceptance zone. So, it could be concluded that the null hypothesis is accepted. However, factors that are fallen inside the rejected zone should be given much more concentration.

They are as follows:

- Organization has hygienic sanitary facility.

- Organization has Dining arrangements.

- Organization provide on time festival bonus.

- Organization Provide Sufficient Transportation facility.

- Organization provides efficiency bonus equitably.

- Organization provides production bonus.

- Organization arranges recreational facilities.

\section{CONCLUSION}

The study of employee welfare facilities in Garments Industries of Bangladesh appears good. The average mean score of the overall of 20 items has been computed at 3.35. The findings of the study suggest that the garments industries in Chittagong city of Bangladesh provide various facilities to the employees and tend to follow the rules and regulation of the Bangladesh Government. However, there are issues such as sufficient medical facilities, hygiene facilities, recreational activity and performance incentives where the challenges still remain as far as the long term sustainability of the organization is concerned. When employees get better facilities like: Enough medical care, assistance in child care, hygienic sanitary facility, safe drinking water, transportation facility, recreational facility, those give employees a high level of satisfaction. This provides opportunity to an organization to grow rapidly and sustainably.

\section{ReCOMmEndations}

The findings and experience of the study come up with the following recommendations:

- Garment factories should consider providing affordable housing facilities to the workers.

- The management should provide the workers with insurance benefit, and food allowances.

- The workers should be allowed for regular recreational facilities to keep themselves mentally healthy. 
- The workers should be allowed for performance incentives to boost their efficiency, productivity and loyalty.

- Because of multiple and versatile advantages of compliance, the garment industries should ensure the proper placement and practice of Code of conduct of compliance.

- To end the exploitation of workers and to make the enterprise more sustainable, the establishment of independent trade unions to monitor and protect worker's right should be encouraged with keeping enough room for workers' participation and engagement in the company's decision making process.

\section{REFERENCES}

Ahmed, H.U. (2014). RMG sector: Opportunities and challenges. Available: http:/ / www.thefinancialexpressbd.com/2014/10/04/59623/print. Last accessed 24th Oct 2015.

Bhoumik, N. (2014). Bangladesh's Garment Factories Still unsafe for workers. Available: http://time.com/21038/bangladeshsgarment-factories-still-unsafe-for-workers-says-report/. Last accessed 22th Aug 2015.

Borman, W.C.C. (2000), "The Concept of Organization Citizenship: Current Directions", Psychological Science,13, p238-241

Hassan, F. (2014). RMG industry of Bangladesh; Past, present and future. Available: http://www.dhakatribune.com/longform/2014/sep/19/rmg-industry-bangladesh-pastpresent-and-future. Last accessed 24th Oct 2015.

Hossain, I. (2014). RMG export earnings grow 5\% despite all odds in 2015.2 Available: http:/ / www.dhakatribune.com/business/2014/dec/28/r mg-export-earnings-grow-5-despite-all-odds-2014. Last accessed 24th Oct 2015.

ILO(2015). "Improving Working Conditions in Readymade Garments Sector (RMGP) Programme In Bangladesh". Available at: http:/ / www.ilo.org/dhaka/Whatwedo/Projects/safergarment-industry-in-bangladesh/WCMS_226530/lang-en/index.htm Last Accessed on 12 January 2015.

Iqbal, M. and Yilmaz, Ayse K. (2014) "Analysis of Workplace Stress and Organisational Performance in Human Resource Management: A Case Study of Air Traffic Controllers of Pakistan", International Journal of Management and Sustainability, 3(6), p360-373.

JetHR. (2015) Employee Welfare - What Is Employee Welfare. [Online] Available from: http:/ / www.jethr.com/magazine/human-resourcemanagement/employee-welfare-what-is-employeewelfare/article.html [Accessed: 27th July 2015]

Kongala, R. (2013), "Motivation and Workforce Performance in Indian Industries", Research Journal of Management Sciences, 2(4), p25-29.
Odeku, Olufunmilayo F. and Odeku, Kola O. (2014). “In Pursuit of the Employees' Welfare in the Workplace: Issues in Perspectives", Mediterranean Journal of Social Science, 5(15), p652-660.

Patro, C.S. (2012), "Employee Welfare Activities in Private Sector and Their Impact on Quality of Work Life", International Journal of Productivity Management and Assessment Technologies, 1(2), p19-30.

Phillips, R. (2003). "Stakeholder Theory and Organizational Ethics". San Francisco: Berrett-Koehler Publishers, Inc. p166.

Rahman, M. and Hossain, M. (2010) Compliance Practices in Garment Industries in Dhaka city. Journal of Business and Technology (Dhaka). 5 (2). p.71-87.

Rynes, Sara L., Gerhart, B. and Minette, Kathleen A. (2004). "The Importance of Pay in Employee Motivation: Discrepancies between What People Say and What they do", Human Resource Management, 43(4), p381-394.

Sindhu, S. (2012). Role of organization in welfare measures for employees. International Journal of Research in IT $\mathcal{E}$ Management. Vol 2 (9), p36-40. Available from: $<$ https: / / www.google.com.bd /url?sa $=$ t\&rct=j\&q=\&esrc=s \&source $=$ web\&cd $=4 \&$ ved $=0$ CDIQFjADahUKEwjp7cq8r_nI AhXGlogKHUt_BRE\&url=http $\% 3 \mathrm{~A} \% 2 \mathrm{~F} \% 2 \mathrm{Fwww}$.euroasia pub.org\%2Fdownload.php\%3F\%2520filename\%3Dvz9PZ1 AiX5bXe7L.pdf\%26new\%3D5.pdf\&usg=AFQjCNHM4GfE $\mathrm{Vb} 4 \mathrm{CHERLi}-$ v5ChH8IOWJmQ\&sig2=YpJeN2h_oM3WkyEh_uhjAw $>$. [Accessed on: 5th Nov, 2015]

Slaper, Timothy F. and Hall, Tanya J. (2011). "The Triple Bottom Line: What is it and How Does It Work". Indiana Business Review. Spring, p1-8.

Srinivas, K. T. (2013). "A Study on Employee Welfare Facilities adopted at Bosch Limited, Bangalore". Research Journal of Management Science. 2(12). p7-11.

Symons, C. and Lamberton, G. (2014). "Building a Social Case for Business Sustainability", Journal of Economic and Social Policy, 16(2), Article-9.

Tiwary, U. (2014). A Study On Employee Welfare Facilities And Its Impact On Employees Efficiency At V Indha Telelinks Ltd. Rewa (M.P. ) India. Abhinav International Monthly Refereed Journal of Research in Management E Technology. 3 (6). Available from: <http:/ / abhinavjournal.com/journal/index.php/ISSN2320-0073/article/view/451>. [Accessed on: 25th Oct, 2015]

Venugopal P., Bhaskar T. and Usha P. (2011) "Employee Welfare Activities with Respective Measures in Industrial Sector-A Study on Industrial Cluster At Chittor District", International Journal of Research in Commerce, IT and Management, 1(6), p78-84

Webb, N.J. and Blandin. J. (2006). “Evaluating Executive Performance in the Public Sector, International Public Management Review, 7, p98-117 


\section{APPENDIX}

Table: Calculation of Mean and Standard Deviation of Each Factor

\begin{tabular}{|c|c|c|c|}
\hline $\begin{array}{l}\text { Title of the statement } \\
\end{array}$ & $\mathrm{N}=130$ & Mean & Standard Deviation \\
\hline $\begin{array}{c}\text { 1. There is no bonded labor in Your Organization. } \\
\text { Strongly Agree } \\
\text { Agree } \\
\text { Neutral } \\
\text { Disagree } \\
\text { Strongly Disagree }\end{array}$ & $\begin{array}{l}54 \\
43 \\
12 \\
10 \\
11\end{array}$ & 3.91 & 1.25 \\
\hline $\begin{array}{l}\text { 2. Organization Provide Enough Medical Care } \\
\text { Strongly Agree } \\
\text { Agree } \\
\text { Neutral } \\
\text { Disagree } \\
\text { Strongly Disagree } \\
\end{array}$ & $\begin{array}{l}33 \\
34 \\
11 \\
31 \\
21 \\
\end{array}$ & 3.20 & 1.46 \\
\hline $\begin{array}{c}\text { 3. Organization Assists in Child Care } \\
\text { Strongly Agree } \\
\text { Agree } \\
\text { Neutral } \\
\text { Disagree } \\
\text { Strongly Disagree }\end{array}$ & $\begin{array}{l}29 \\
40 \\
26 \\
17 \\
18 \\
\end{array}$ & 3.34 & 1.33 \\
\hline $\begin{array}{l}\text { 4.. Organization Provides Sufficient rest room facility. } \\
\text { Strongly Agree } \\
\text { Agree } \\
\text { Neutral } \\
\text { Disagree } \\
\text { Strongly Disagree }\end{array}$ & $\begin{array}{c}43 \\
49 \\
24 \\
6 \\
8\end{array}$ & 3.86 & 1.11 \\
\hline $\begin{array}{c}\text { 5. Facilities Available for Religious activities } \\
\text { Strongly Agree } \\
\text { Agree } \\
\text { Neutral } \\
\text { Disagree } \\
\text { Strongly Disagree }\end{array}$ & $\begin{array}{l}24 \\
45 \\
16 \\
27 \\
18\end{array}$ & 3.23 & 1.33 \\
\hline $\begin{array}{l}\text { 6. Organization Has Sufficient Fire Safety Measures } \\
\text { Strongly Agree } \\
\text { Agree } \\
\text { Neutral } \\
\text { Disagree } \\
\text { Strongly Disagree } \\
\end{array}$ & $\begin{array}{c}38 \\
47 \\
6 \\
25 \\
14 \\
\end{array}$ & 3.54 & 1.37 \\
\hline $\begin{array}{l}\text { 7. Organization Facilitates with safe drinking water } \\
\text { Strongly Agree } \\
\text { Agree } \\
\text { Neutral } \\
\text { Disagree } \\
\text { Strongly Disagree }\end{array}$ & $\begin{array}{l}58 \\
34 \\
10 \\
16 \\
12 \\
\end{array}$ & 3.85 & 1.35 \\
\hline $\begin{array}{l}\text { 8. Organization has adequate lighting and ventilation. } \\
\text { Strongly Agree } \\
\text { Agree } \\
\text { Neutral } \\
\text { Disagree } \\
\text { Strongly Disagree }\end{array}$ & $\begin{array}{l}47 \\
38 \\
14 \\
15 \\
16\end{array}$ & 3.65 & 1.39 \\
\hline $\begin{array}{c}\text { 9. Organization has hygienic sanitary facility. } \\
\text { Strongly Agree } \\
\text { Agree } \\
\text { Neutral } \\
\text { Disagree } \\
\text { Strongly Disagree }\end{array}$ & $\begin{array}{l}16 \\
27 \\
28 \\
35 \\
24\end{array}$ & 2.82 & 1.29 \\
\hline $\begin{array}{c}\text { 10. Organization has Dining arrangements. } \\
\text { Strongly Agree } \\
\text { Agree } \\
\text { Neutral } \\
\text { Disagree } \\
\text { Strongly Disagree } \\
\end{array}$ & $\begin{array}{l}25 \\
34 \\
17 \\
26 \\
28 \\
\end{array}$ & 3.02 & 1.45 \\
\hline
\end{tabular}




\begin{tabular}{|c|c|c|c|}
\hline $\begin{array}{l}\text { 11. Organization provide on time festival bonus. } \\
\text { Strongly Agree } \\
\text { Agree } \\
\text { Neutral } \\
\text { Disagree } \\
\text { Strongly Disagree }\end{array}$ & $\begin{array}{l}37 \\
28 \\
04 \\
15 \\
36\end{array}$ & 2.88 & 1.62 \\
\hline $\begin{array}{l}\text { 12. Organization Provides enough overtime payments. } \\
\text { Strongly Agree } \\
\text { Agree } \\
\text { Neutral } \\
\text { Disagree } \\
\text { Strongly Disagree }\end{array}$ & $\begin{array}{l}48 \\
47 \\
16 \\
15 \\
04\end{array}$ & 3.92 & 1.11 \\
\hline $\begin{array}{l}\text { 13. Organization Provide Sufficient Transportation facility. } \\
\text { Strongly Agree } \\
\text { Agree } \\
\text { Neutral } \\
\text { Disagree } \\
\text { Strongly Disagree }\end{array}$ & $\begin{array}{l}19 \\
27 \\
24 \\
36 \\
24\end{array}$ & 2.85 & 1.34 \\
\hline $\begin{array}{c}\text { 14. Organization Provides attendance bonus. } \\
\text { Strongly Agree } \\
\text { Agree } \\
\text { Neutral } \\
\text { Disagree } \\
\text { Strongly Disagree }\end{array}$ & $\begin{array}{l}45 \\
47 \\
09 \\
11 \\
18\end{array}$ & 3.69 & 1.38 \\
\hline $\begin{array}{c}\text { 15. Organization provides efficiency bonus equitably. } \\
\text { Strongly Agree } \\
\text { Agree } \\
\text { Neutral } \\
\text { Disagree } \\
\text { Strongly Disagree }\end{array}$ & $\begin{array}{l}19 \\
21 \\
22 \\
33 \\
35\end{array}$ & 2.66 & 1.40 \\
\hline $\begin{array}{c}\text { 16. Organization provides production bonus. } \\
\text { Strongly Agree } \\
\text { Agree } \\
\text { Neutral } \\
\text { Disagree } \\
\text { Strongly Disagree }\end{array}$ & $\begin{array}{l}15 \\
13 \\
16 \\
47 \\
39\end{array}$ & 2.37 & 1.31 \\
\hline $\begin{array}{c}\text { 17. Organization arranges recreational facilities. } \\
\text { Strongly Agree } \\
\text { Agree } \\
\text { Neutral } \\
\text { Disagree } \\
\text { Strongly Disagree } \\
\end{array}$ & $\begin{array}{l}15 \\
15 \\
10 \\
44 \\
46\end{array}$ & 2.3 & 1.36 \\
\hline $\begin{array}{l}\text { 18. Organization provides the equal employment opportunities. } \\
\text { Strongly Agree } \\
\text { Agree } \\
\text { Neutral } \\
\text { Disagree } \\
\text { Strongly Disagree }\end{array}$ & $\begin{array}{l}45 \\
36 \\
19 \\
21 \\
09\end{array}$ & 3.67 & 1.29 \\
\hline $\begin{array}{c}\text { 19. Organization does not have workplace violence. } \\
\text { Strongly Agree } \\
\text { Agree } \\
\text { Neutral } \\
\text { Disagree } \\
\text { Strongly Disagree }\end{array}$ & $\begin{array}{l}43 \\
22 \\
19 \\
28 \\
18\end{array}$ & 3.34 & 1.47 \\
\hline $\begin{array}{c}\text { 20. Employees are not harassed by the top level executives. } \\
\text { Strongly Agree } \\
\text { Agree } \\
\text { Neutral } \\
\text { Disagree } \\
\text { Strongly Disagree }\end{array}$ & $\begin{array}{l}55 \\
38 \\
11 \\
20 \\
06\end{array}$ & 3.89 & 1.24 \\
\hline
\end{tabular}


Publish Online and Print Version Both

Online ISSN: 2305-8730

Online Archive: http://journals.abc.us.org/index.php/abr/issue/archive

Indexed Archive Links

OCLC WorldCat: http://goo.gl/vhQzla

Google Scholar: https://goo.gl/t23FeQ abcGATE: http://goo.g1/E6WdgA

BASE: $\underline{\mathrm{http}: / / g o o . g 1 / \mathrm{sEd} 0 \mathrm{SZ}}$

\section{5.) WorldCat}

\section{Google scholar}

